\title{
VISUAL AND VERBAL SIGNS IN LINE MESSENGER APPLICATION: A SEMIOTIC STUDY
}

\author{
Venice Wijaya'; Thyrhaya Zein ${ }^{2}$ \\ Universitas Sumatera Utara1,2 \\ Corresponding email: venicewijaya@gmail.com
}

\begin{abstract}
The use of stickers especially in LINE Messenger application is very popular among teenagers, although misunderstanding is often occurred. The reason for choosing LINE stickers is that they are full-sized and expressive so that many users misunderstand in employing it. In addition, LINE provides a wide range of stickers, and that is very important for users to understand the meaning of each sticker to avoid misunderstanding. This study aims to identify visual and verbal signs contained in LINE messenger. Employing a qualitative descriptive research design, the researchers analyzed visual and verbal signs of 20 stickers and texts taken from LINE Messenger application. The stickers are the main data while the texts are employed to support the data. The data were then analyzed by using semiotic theory with a trichotomy model proposed by Peirce. The results show that every sticker contains qualisign aspects. It is also shown that every sticker is replica, but refers to the law. Every sticker must also share at least one similar characteristic or icon with the object they represent and the sticker used must base on the topic which occurred. The symbol is in the form of keyword, making it easier for the user to choose the sticker variations. Rheme and dicent turn out that meaning can be derived from the elements that contained in the stickers. While rheme contain qualisign and icon only, dicent contains secondness aspects. Arguments show that meaning can be derived from hypotheses, standards in society, or even the sign itself.
\end{abstract}

Keywords: visual, verbal, sign, semiotics, trichotomy

\section{INTRODUCTION}

Along with the growth of technologies, people can express their words easier. Messages itself can also be created by nonverbal systems (code). In LINE application, people can express their words with stickers. This shows that a sticker has the power of words (Wang, 2016). But at the same time it 
can also be ambiguous and misunderstand, this is why people must also learn about the meaning contained in stickers.

LINE, a messenger application, was first invented by Naver, Korea, in 2000, which in 25 th November 2013, it reached 300 million users. Different from another messenger application, LINE is the only application which offers more than 10,000 stickers with various kinds of stickers. The variation of 'LINE sticker' provides the users with many kinds of emotion 'Sticker' which also are considered as a form of writing included in the pictographic writing. Pictographic writing itself is one of the kinds of writing which consist of picture signs (The Evolution of Writing, n.d.). Picture sign is used to represent an object that they explained.

Semiotics is an ideal tool which served as guidance to analyze a specific set of signs (sticker), such as the discipline of studying and documenting signs, sign behavior, sign creation, and sign functions. This is why semiotics is used as a generic tool to imply the data. Danesi (2016) defines a sign as any physical form that represent something other than itself in some specific context. Peirce defines a sign as a representament with a mental interpretant or can also be called as "cognition of mind" (Noth, 1991).

There have been some previous studies related to this study. The first is from Nilasari et al. (2018), which have the same data with this study. The difference is that this study only focuses on the full sized sticker, in which it contains gestures with its full sized body, and this gives much more information than the emoticon (small sized sticker). The writer also describes the elements contained in the visual signs. The second one is from Saputro. Our study used similar theory, but the difference is his study did not identify the elements in visual signs, but only discussed about the meaning of the visual signs through the relationship of the representamen, object and interpretant. Aside of it, writer also use some other published articles as references, such as Jessica \& Franzia's (2017).

The similarity of their study with this study is in the data, in which both of them analyze a full sized sticker. The difference is this study used Peirce's theory of signs meanwhile their study used Saussure's theory, from Franzia (2019) the similarity of her study and this study is laid on the data, in which both are full-sized sticker, and from Napitupulu et al. (2018) the similarity of her study and this study is that both using a visual analysis study. Meanwhile the difference is that this study employs Peirce's theory meanwhile her study use Halliday's theory. This study aims to identify visual and verbal signs contained in LINE messenger who might be useful for linguistic semiotic studies, visual communication design, and other readers whose discussion related to visual semiotic. It is also useful to develop the knowledge about the description and meanings contained in LINE sticker. 


\section{METHODS}

This study employs qualitative descriptive research which concerns with qualitative phenomenon such as human behavior (Kothari, 2004). The descriptive method means that the writer give a deep description related to the data. Data source of this study is LINE messenger. The data of this study is visual (stickers) as the main data and verbal (texts) as supporting data. The method in collecting data is by documentation. The data is analyzed by using content-analysis technique. Content analysis is a research technique to make a valid inferences from texts (or other meaningful matter) to the contexts of their use (Krippendorff, 2004).

In collecting data for this study, the writer chooses the documentation method from one of the popular digital messaging application, LINE messenger. After collecting the screenshots, the writer employs contentanalysis method.

\section{Data Analysis Procedures}

After collecting the data, writer firstly does a unitizing. In this step, the writer groups or distinguishes part of the data, in which it consists of verbal and visual texts. Then the writer sorts out the sticker. The next step is sampling. In this step, the writer limits the observation to make sure none of the sticker being analyzed twice. Next, the writer does a coding. In this step, the writer thickens the phrase which supports the sticker to make differences in the relationship of verbal and visual in each data. Afterwards, the writer reduces the data to the important or related parts. In this section, the writer cut down the data into only the main data.

The next step is the most important step, inferring. This is the unique step which contained in the content analysis. In content analysis, this step is very important because it is used as evidence for the findings. This step is also called as analyzing step. In analyzing the data, the writer grouped the data based on the elements contained in the visual signs. In this step, the writer used the Peirce's classification of signs theory or the three trichotomies (Jappy, 2013). The first trichotomy consists of the qualisign, sinsign, and legisign. The second trichotomy consists of the icon, index, and symbol. Meanwhile the third trichotomy consists of rheme, dicent, and argument.

After analyzing and get the findings, the next step is narrating. In this step, the writer gives a description about the findings to make it clearer for the reader. In content analysis, some steps can be repeated more than once if needed until the writer reached the certain goal, especially when the writer verify or recheck the analysis. 


\section{FINDINGS}

Based on the analysis of the first trichotomy, it is shown that every sticker has a qualisign aspects on it such as the colors, gestures, shape, etc; legisign, which is the law of the sticker based on the standard that exist in the society; and sinsign, in which every sticker is a replica, for they have been modified. It can be seen that stickers which is attached with words does not affected by the quality contained on it, such as the color and the size. Color, shape, and other quality are very important for the stickers that give meanings by their acts. It can also be seen that by using the verbal text as supporting data, the meaning of the sticker becomes clearer, as it related to the topic of the conversation.

Based on the analysis of the second trichotomy, every sticker have an iconic aspects on it, in which every stickers must at least shares one similar characteristics with the real object that it represents, no matter it is the shape, the color, the acts, or any other aspects. But then, one sticker can also represent some meanings. This is why the supporting verbal (text) is needed, to emphasize the usage of the sticker. Symbol itself is the key word of the sticker.

Based on the analysis of argument, it is shown that meaning can be derived from hypotheses, customs in society (law), or from the signs itself. In the other hand, rheme and dicent show that meaning can be derived if we know the characteristics of the stickers and relate it to the conversations occurred.

\section{DISCUSSION}

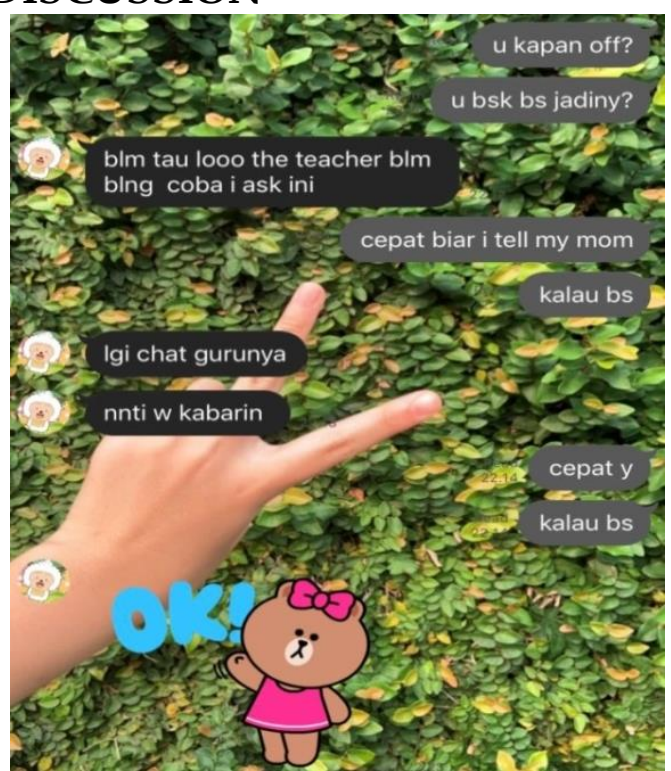

Fig 1. Screenshot chat of $\mathrm{M}$ and $\mathrm{A}$

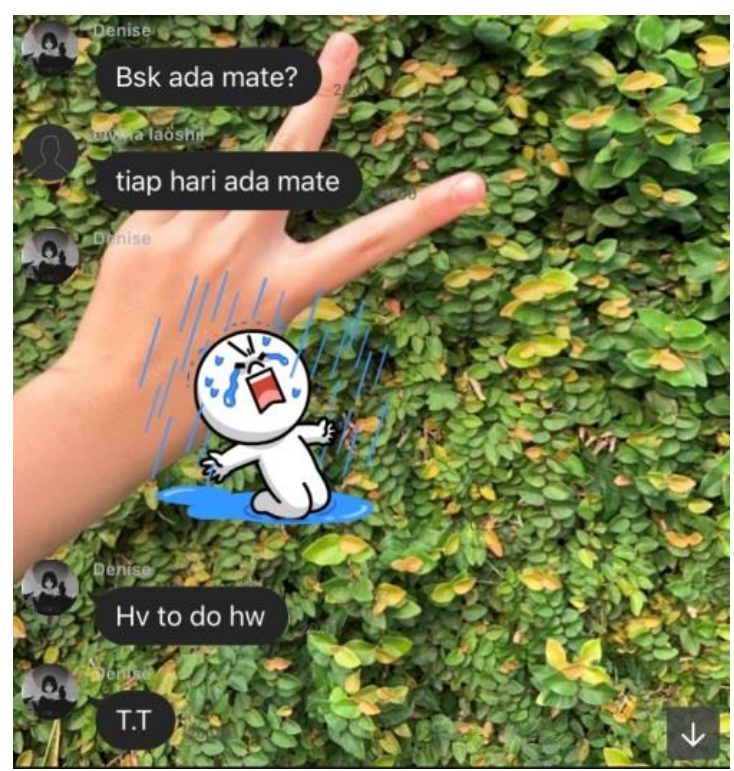

Fig2. Screenshot chat of group 9b WOWOW 
The first screenshot above showed the conversation between ' $M$ ' and ' $A$ ' in which it consists of visual (sticker) as the main data and verbal (written texts) as the supporting data. Next to it, the second screenshot, showed the conversation between ' $\mathrm{D}$ ' and 'EL' in the group chat, which also consists of visual (sticker) as the main data and verbal (written texts) as the supporting data. Based on the stickers and written texts above, the elements of the sticker can be identified by using the three trichotomy theory as what can be seen below:

\section{First Trichotomy}

The first trichotomy divided into three categories: qualisign, sinsign, and legisign. Qualisign is the qualities components contained in the material sign, such as color, gestures, ecpression, etc. Sinsign is a sign which is an actual existent thing or event. Legisign is the law of sign.

Table: 1 First Trichotomy Analysis

\begin{tabular}{|c|c|c|c|}
\hline Data & Qualisign & Sinsign & Legisign \\
\hline & \multirow[b]{2}{*}{$\begin{array}{l}\text { In this sticker, it can be seen that } \\
\text { 'Brown's' hand is pointing on the } \\
\text { blue-colored "ok" word. }\end{array}$} & $\begin{array}{l}\text { OK word sticker is } \\
\text { used as the replica of } \\
\text { the general OK word }\end{array}$ & \multirow{2}{*}{$\begin{array}{l}\text { The "OK" } \\
\text { word is } \\
\text { commonly } \\
\text { used in the } \\
\text { society to } \\
\text { show } \\
\text { 'agreement }\end{array}$} \\
\hline $\begin{array}{l}\text { "cepat, } \\
\text { kalau bs" }\end{array}$ & & $\begin{array}{l}\text { It can be proved by the } \\
\text { written text in which } \\
\text { user ' } \mathrm{M} \text { ' used it as } \\
\text { reponse towards the } \\
\text { request of user ' } \mathrm{A} \text { '. }\end{array}$ & \\
\hline a & \multirow{2}{*}{$\begin{array}{l}\text { In this sticker, it can be seen that there } \\
\text { are blue-colored tears running down } \\
\text { through 'Moon's' face. It can also be } \\
\text { seen that he's showing a wide-opened } \\
\text { mouth which is square-shaped and he } \\
\text { also wrinkled his eyebrows and it can } \\
\text { also be seen that the blue-colored rain } \\
\text { is pouring on his wide-opened hand }\end{array}$} & $\begin{array}{l}\text { Cry sticker is used as } \\
\text { replica of the general } \\
\text { sign of crying act }\end{array}$ & \multirow{2}{*}{$\begin{array}{l}\text { Tears is a } \\
\text { commonly } \\
\text { known in } \\
\text { the society } \\
\text { as the sign } \\
\text { of 'sadness' }\end{array}$} \\
\hline $\begin{array}{l}\text { "tiap } \\
\text { hari ada } \\
\text { mate" }\end{array}$ & & $\begin{array}{l}\text { It can be proved by the } \\
\text { written text in which } \\
\text { user ' } \mathrm{D}^{\prime} \text { used it to react } \\
\text { to the information } \\
\text { given by user ' } \mathrm{E}^{\prime}\end{array}$ & \\
\hline
\end{tabular}

Every sticker contained qualities that can affect or give meanings of the sticker. The quality can be the color, the expression, the gestures, etc. In some case, the meaning in the sticker is based on the quality contained in it, such as what is shown in the second data, in which the colors (tears and rain colors), gestures (kneeling and wide-opened hand under the rain), and also the facial expressions (wrinkled eyebrow and wide-opened mouth) showed the meaning of the sticker. But in some case, the quality didn't affect the meaning, the example of the case can be seen above in which the 'OK' word has directly give the meaning of the sticker, the gestures of Conny and the color of the word did not affect the meaning of the sticker. 
Every sticker is also a replica, because they have been modified. It means that every sticker is a sinsign. But then, they still follow the general word or meaning which has been known in the society, by that, the society can understand the meaning of the sticker when the supporting word did not exist in the sticker. The example is the 'OK' word above is a modified type, from the color, the shape, the capitalization, etc. which is why it is a sinsign, but it also refers to a law, legisign, which is a general OK word. In the other hand, in the second sticker it can be said that not every gestures of crying is has to occur under the rain. So it can also be said that the sticker is the replica of the real crying act that it represent. But it still refers to the law, crying act.

However, every sinsign always refers to a law; this is what called as legisign. A law means is the standardization or the meaning or perception which has been agreed in the society. The first example from the sticker above is the 'OK' word. This word has been known generally in the society to be the word used to show agreement to a request or a statement. The second example can be seen from the second data in which the legisign is the 'sadness' word. The act of crying as shown in the sticker has been well known in the society as the act to show the sadness of someone.

\section{Second Trichotomy}

The second trichotomy divided into icon, index, and symbol. Icon is a sign that possess the character which gives it significant (meaning) no matter its object has or doesn't has existence. Index is a sign which would lose the character which make it a sign if its object were removed. Symbol is a sign that would lost its character which causes it a sign if there were no interpretant (meaning)

Table: 2 Second Trichotomy Analysis

\begin{tabular}{|c|c|c|c|}
\hline Sticker & Icon & Index & Symbol \\
\hline okgen & $\begin{array}{c}\text { The sticker besides is the icon of } \\
\text { showing an OK or agreement in which } \\
\text { people usually use OK word to show } \\
\text { their agreement }\end{array}$ & $\begin{array}{l}\text { The Ok sticker is used } \\
\text { by user ' } \mathrm{M} \text { ' to show an } \\
\text { agreement towards } \\
\text { the request of user ' } \mathrm{A} \text { ' }\end{array}$ & $\begin{array}{l}\text { The symbol } \\
\text { of this } \\
\text { sticker is the } \\
\text { 'OK' word }\end{array}$ \\
\hline 涳 & $\begin{array}{l}\text { The sticker besides is the icon of the } \\
\text { crying acts in which it shares the same } \\
\text { aspects with the real object, the tears, } \\
\text { the pouring rain, and the kneeing } \\
\text { feet, as if in the film where there's } \\
\text { someone crying under the rain while } \\
\text { kneeing on his feet. }\end{array}$ & $\begin{array}{l}\text { The crying sticker } \\
\text { beside is used by user } \\
\text { ' } D \text { ' to show his sad } \\
\text { feelings towards math } \\
\text { class and the answer } \\
\text { from user ' } E \text { ' }\end{array}$ & $\begin{array}{l}\text { The symbol } \\
\text { of this } \\
\text { sticker is } \\
\text { the 'cry' } \\
\text { word }\end{array}$ \\
\hline
\end{tabular}


In Icon, it can be seen that every sticker must have at least one similarity to the object or the meaning that they represent. The first example can be seen above in which the sticker share the same characteristic, ' $O K^{\prime}$ word. But then it also has another modifier, such as the color, the brown character, and the exclamation mark. Meanwhile in the second example it can be seen that the similar characteristic shared by the sticker are the tears, and the kneeling gestures which is then emphasized by the pouring rain. The real act that the sticker represented also has such characteristics, in which people always shed tears when they cry.

Index is used to show the main reason why the sticker is used by the user and to whom the sticker is addressed to. It is like the reason why the sticker is used. The first example from the case above is the sticker is used by user ' $M$ ' for user ' $A$ ' to show that ' $M$ ' is agree with the request stated by ' $A$ '. Based on that reason, there is the meaning for the existence of the sticker above. The other example from the second case above is the sticker is used by user ' $\mathrm{D}$ ' to show his sad feelings after he heard the information given by 'EL' that everyday have math.

Symbol acts as the key word of the sticker. The key word here means that when the user wanted to use the sticker, the user only have to type the keywords and the variations of stickers with the same key words appeared, and the user can choose which variation they wanted to use. The keyword of the first example has been clearly shown in the sticker which is the ' $O K$ ' word. Meanwhile the keyword of the second sticker lay on the act of it, which is 'cry'.

\section{Third Trichotomy}

The third trichonomy divided into: rheme, dicent, and argument. Rheme is a sign of qualitative possibility understood as representing such a kind of possible object. Dicent is when there's a real relation between the representamen and the interpretant. Argument is when the representamen and the interpretant have a general characteristic, or a law. 
Table: 3 Third Trichotomy Analyses

\begin{tabular}{|c|c|c|c|}
\hline Data & Rheme & Dicent & Argument \\
\hline okros & $\begin{array}{l}\text { The sticker beside is } \\
\text { rhematicindexialsinsign } \\
\text { because the 'OK' word } \\
\text { is the only object that } \\
\text { affect the meaning of the } \\
\text { sticker, in which it } \\
\text { represent the general } \\
\text { word for agreement. It } \\
\text { is a replica because it } \\
\text { can be repeated and it } \\
\text { represent the general ok } \\
\text { word }\end{array}$ & $\begin{array}{l}\text { The sticker beside is } \\
\text { dicentindexiallegisign } \\
\text { because the indicator in the } \\
\text { sticker is only the 'OK' } \\
\text { word and not the act, } \\
\text { although there's still a } \\
\text { character 'Brown' next to } \\
\text { the word. The OK itself is a } \\
\text { general word,in which it is } \\
\text { related to the meaning of } \\
\text { the sticker which is to state } \\
\text { an agreement }\end{array}$ & $\begin{array}{l}\text { The sticker beside is a } \\
\text { (deduction) argument } \\
\text { symbolic legisign } \\
\text { because in the society } \\
\text { whenever we answer } \\
\text { someone with an 'OK' } \\
\text { word it means that } \\
\text { we're showing an } \\
\text { agreement and this } \\
\text { sticker contain the 'OK' } \\
\text { word which represents } \\
\text { the 'OK' word in } \\
\text { generally }\end{array}$ \\
\hline (8) & $\begin{array}{l}\text { The sticker beside is } \\
\text { rhematic iconic } \\
\text { qualisign because the } \\
\text { blue-colored tears } \\
\text { represent the sadness, in } \\
\text { which the blue-colored } \\
\text { tears is the quality } \\
\text { contained in the sticker, } \\
\text { which represents the } \\
\text { sadness. It is a replica of } \\
\text { the general crying act. }\end{array}$ & - & $\begin{array}{l}\text { The sticker beside is } \\
\text { rhematic iconic } \\
\text { qualisign because the } \\
\text { blue-colored tears } \\
\text { represent the sadness, in } \\
\text { which the blue-colored } \\
\text { tears is the quality } \\
\text { contained in the sticker, } \\
\text { which represents the } \\
\text { sadness. It is a replica of } \\
\text { the general crying act. }\end{array}$ \\
\hline
\end{tabular}

From the first data, it can be seen that it is a rhematicindexialsinsign, because the 'OK word which is attached on it has given the clear meaning of the sticker. Meanwhile in the second data it can be seen that it is a rhematic iconic qualisign. This is because the meaning of the sticker is derived from the gestures, face expressions, and colors on the sticker.

In dicent, it can be seen that the first sticker is included as dicent indexial legisign because the ' $\mathrm{OK}^{\prime}$ ' word itself has given the meaning and is a law, no matter it is modified or not. Meanwhile the second sticker didn't have any dicent because the meaning is fully based on the quality contained in the sticker.

In argument, the first sticker is included as deduction because the 'OK' word has justifies the meaning itself. In the other hand, the second sticker is included as abduction because the meaning of the sticker is based on the hypothesis of the characteristics contained in the sticker

Based on the theory, sign is divided into three trichotomies, the first trichotomy is based on the point of view of the representamen, the second trichotomy is based on the relationship between representamen and object, meanwhile the third trichotomy is based on the interpretant itself. 
The third trichotomy consist all aspects on the first and second trichotomy. The difference is dicent do not have the qualisign and iconic aspects because it is a secondness. Dicent can be divided into (1) dicent indexial sinsign, (2) dicentindexiallegisign, and (3) dicent symbolic legisign. The sticker above is included as dicentindexiallegisign. It is an indexiallegisign because it is in the form of word, and the word is the one which needed to be focused on, because the gestures of the 'Brown' character and the other aspects did not gives any help in describing the meaning of the sticker. And the ' $\mathrm{OK}^{\prime}$ word is a general word to state an agreement.

Meanwhile rheme consist of every aspects included qualisign and iconic, because it laid on the firstness. Rheme can be divided into (1) Rhematic iconic qualisign, (2) Rhematic iconic sinsign, (3) Rhematic iconic legisign, (4) Rhematicindexialsinsign, (5) Rhematicindexiallegisign, and (6) Rhematic symbolic legisign. The sticker above is included as rhematicindexialsinsign. It is a sinsign because the 'OK' word is a replica of the real word. This can be seen from the additional of color and the exclamation mark, also the 'Brown' character next to it.

In the other hand, there is only one type of argument, which is argument symbolic legisign. Argument is always symbolic because it is described by using words and it is also legisign because it is based on the knowledge of the society or the law that exist in the society.

\section{CONCLUSION AND SUGGESTION}

In some cases, the colors on the sticker do not affect the meaning contained on it. In the other hand, sticker with clear object which refers straightly to the meaning can still be affected by the colors of the object. Other than that, actions in the sticker with word help to reinforce the meaning of the sticker. It is also shown that every sticker is a replica, because it has been modified. But then, all stickers still refer to the law, which makes it easier for the society to understand the usage of the sticker.

Every sticker must also have the least one similar characteristic with the object they. Because when it comes to the meaning in the sticker, it is found that stickers with the same general meaning can be used as response towards different condition. To make user easier, there is a key word which can be typed and the variations of the sticker can be chosen. This key word is called as symbol.

It is suggested that this research can be developed into a more specific explanation, such as the meaning of each colors, gestures, properties, etc. The writers hope that this research can be useful to everyone who read it, especially to be used as a reference for the upcoming research to increase 
readers' knowledge related to the elements on visual, the realization of the visual, and semiotics.

\section{REFERENCES}

Danesi, M. (2016). The Semiotics of Emoji. Bloomsbury Publishing.

Franzia, E. (2019). Aspek Keunikan dan Komunikasi Visual pada Stiker

LINE (Studi Kasus: Stiker "Cony Special Edition”, "Soekirman Si

Tukang Parkir", dan "Baba Kiko"). ANDHARUPA: Jurnal Desain

Komunikasi Visual \& Multimedia.

https://doi.org/10.33633/andharupa.v5i01.2049

Jappy, T. (2013). Introduction to Peircean Visual Semiotics. In Introduction to

Peircean Visual Semiotics. https://doi.org/10.5040/9781472541963

Jessica, G., \& Franzia, E. (2017). The Analysis of Line Sticker Character

"Cony Special Edition." Humaniora.

https://doi.org/10.21512/humaniora.v8i3.3904

Kothari, C. R. (2004). Research Methodology : Methods and Techniques -

RES701DUMP $\backslash$ References $\backslash$ Research Methodology - Methods and

Techniques. In New Age International.

https://doi.org/http://196.29.172.66:8080/jspui/bitstream/123456789

/2574/1/Research\%20Methodology.pdf

Krippendorff, K. (2004). Content Analysis: An Introduction to Its

Methodology (second edition). In SAGE Publications.

https://doi.org/10.1103/PhysRevB.31.3460

Napitupulu, L. H., Bako, E. N., Ars, N. R., \& Zein, T. (2018). A Multimodal

Analysis of Advertisement of Online Marketplace Shopee. KnE Social

Sciences. https://doi.org/10.18502/kss.v3i4.1955

Nilasari, N. L., Sudipa, I. N., \& Sukarini, N. W. (2018). Sticker Emoticons

Used in LINE Messenger; A Semantic Study. Humanis.

https:/ / doi.org/10.24843/jh.2018.v22.i03.p03

Noth, W. (1991). Handbook of semiotics. In Choice Reviews Online. Indiana

University Press. https://doi.org/10.5860/choice.28-4342

The Evolution of Writing. (n.d.). Marcus 1992, 1-15.

Wang, S. S. (2016). More Than Words? The Effect of Line Character Sticker

Use on Intimacy in the Mobile Communication Environment. Social

Science Computer Review. https:/ / doi.org/10.1177/0894439315590209 